\title{
コロトコフ音スペクトルと冠動脈硬化危険因子との関 連性について
}

\author{
森反 俊幸, 片山 貴文, 斎藤 正男, 矢崎 義雄 ${ }^{*}$, \\ 桜井昇 ${ }^{* *}$, 吉永英世**
}

\section{1. 序 言}

動脈硬化性疾患としての脳卒中, 虚血性心疾患 による死亡数は依然多く，これらの疾患を予知し 予防することは重要な問題である。この問題を解 決するためには，まず動脈硬化の程度を定量的に 診断する必要がある。しかし現在の健康診断はか ならずしも動脈硬化の程度を定量的に診断してお らず，上記疾患が発症するまで見落されることが 多い。我々はすでに収縮期のコロトコフ音は乱流 に起因する音であることを報告し，この乱流周波 数が血管壁の硬度と関連している可能性について 指摘してきた ${ }^{1)}$ 。さらに健常者と虚血性心疾患患 者について収縮期圧，拡張期圧でのコロトコフ音 波形, 脈波形, コロトコフ音スペクトルを分析し 血管壁硬度との関連について合理的なパラメータ 設定をおこなった ${ }^{2)}$ 。その知見をもとに人間ドッ クで適用可能でかつ簡便な動脈硬化の無侵襲定量 的診断法を提案し本診断法の有用性について人間 ドックで使用し血液生化学デー夕 (AI) との比較 検討を行った ${ }^{3)}$ 。本研究は冠動脈硬化危険因子と 提案した動脈硬化診断法との関連性を調べたもの である。

Study on Relationship between Korotkoff Sound Spectrum and Risk Factors for Coronary Arteriosclerosis 東京大学医学部医用電子研究施設

*同第 3 内科

**虎の門病院健康医学センター

(1991 年 7 月 17 日受稿)

\section{2. 対象および方法}

$20 \sim 30$ 歳代健常者 6 名, 40 歳代健常者 17 名, 50 歳代健常者 17 名を対象にして安静時及び運動 負荷後に空気伝導型の脈波・コロトコフ音記録計 で血圧，コロトコフ音波形，脈波形を記録し A/D 変換後 FFTによりコロトコフ音スペクトルを分 析した。また虚血性心疾患患者 39 名 (45〜80 歳, 男性 22 人，女性 17 人平均年齢 59.9 歳)を対象に 安静時での血圧, コロトコフ音波形, 脈波形を記 録し同様の解析を行った。さらに 16 次の線形予測 分析法によりコロトコフ音スペクトル包絡線をも とめた。また人間ドック受診者 83 名 (30〜 68 歳, 男性 66 名, 女性 17 名平均年齢 47.9 歳)について 総コレステロール(以下 TC と略す)，トリグリセ リド(以下 TG と略す), HDL-コレステロール(以 下 HDL-C と略す)，LDL-コレステロール(以下 LDL-C と略す), 動脈硬化指数 (以下 AI と略す), 喫煙, 飲酒, 家族歴と本診断法との比較を行った。 LDL-C は Friedwald の計算式 ${ }^{4)}$

$$
\text { LDL-C }=(\mathrm{TC})-(\mathrm{HDL}-\mathrm{C})-(\mathrm{TG} / 5)
$$

より求めた。また動脈硬化指数 $\mathrm{AI} \mathrm{I}^{5}$ は

$$
\mathrm{AI}=\{(\mathrm{TC})-(\mathrm{HDL}-\mathrm{C})\} /(\mathrm{HDL}-\mathrm{C})(2)
$$

より算出した。異常值の判定は動脈硬化学会 （1987）に基づいた。 TC は $220 \mathrm{mg} / \mathrm{dl}$ 以上を, TG は $150 \mathrm{mg} / \mathrm{dl}$ 以上を, $\mathrm{HDL}-\mathrm{C}$ は $40 \mathrm{mg} / \mathrm{dl}$ 以下 を, LDL-C.は $150 \mathrm{mg} / \mathrm{dl}$ 以上を $\mathrm{AI}$ は 3 以上をそ れぞれ異常值とした。

\section{3. コロトコフ音スペクトルの特性}

図 1 に健常者のコロトコフ音スペクトルの包絡 


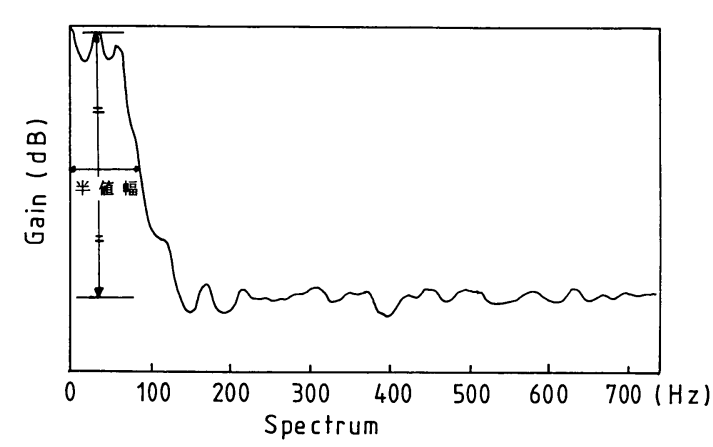

図 1 健常者のスペクトル包絡線

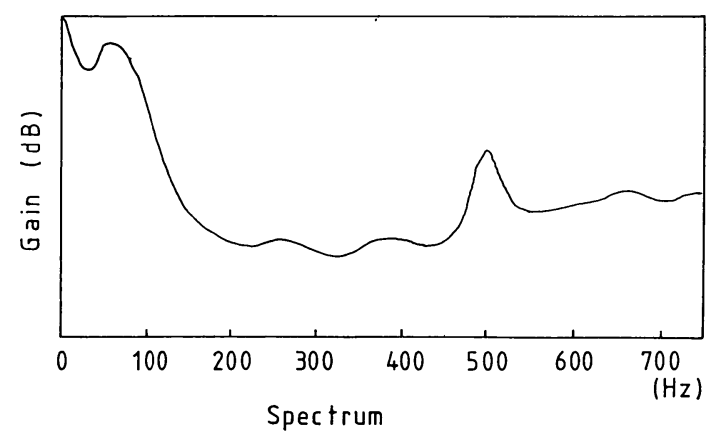

図2 虚血性心疾患患者のスペクトル包絡線

線を, 図 2 に虚血性心疾患患者のコロトコフ音ス ペクトルの包絡線を示す。ピーク值は 20～30 歳代 健常者で $22 \mathrm{~Hz}, 40$ 歳代で $22.9 \mathrm{~Hz}, 50$ 歳代で $25.9 \mathrm{~Hz}$ であり, 年齢とともに増加する。これは加 齢による血管硬化と思われる。正常值を統計にし たがって $22.47 \pm 5.99 \mathrm{~Hz}$ すなわち $28.46 〜 16.48$ $\mathrm{Hz}$ と決める。同様に半值幅は 20〜30 歳代 38 $\mathrm{Hz}, 40$ 歳代 $43.8 \mathrm{~Hz}, 50$ 歳代 $44.1 \mathrm{~Hz}$ である。正 常值は $40.3 \pm 10.4 \mathrm{~Hz}$ すなわち $50.7 \sim 29.9 \mathrm{~Hz}$ とする。虚血性心疾患患者のスペクトル包絡線は 高周波での変動が見られたりスペクトルのピーク 值が高くまた半值幅が広いことがわかる。虚血性 心疾患患者のスペクトルピーク值は $48.5 \mathrm{~Hz}$, 半 值幅 $91.5 \mathrm{~Hz}$ となり健康者の值と比較してスペ クトルのピーク值も半值幅も 2 倍前後高いことが わかる。表 1 に健常者と虚血性心疾患患者でのピ 一ク值, 半值幅, 高周波の異常出現率を示す。虚 血性心疾患患者の群で異常出現率が極めて高いこ
表 1 各パラメータの異常出現率

\begin{tabular}{|c|c|c|}
\hline & $\begin{array}{c}\text { 健常者 } \\
(\mathrm{n}=40)\end{array}$ & $\begin{array}{c}\text { 虚血性心疾患患者 } \\
(\mathrm{n}=39)\end{array}$ \\
\hline ピ - ク異常 & $20 \%$ & $89.7 \%$ \\
\hline 半値幅異常 & $25 \%$ & $100 \%$ \\
\hline 高周波異常 & $27.5 \%$ & $89.5 \%$ \\
\hline
\end{tabular}

とがわかる。このことから動脈硬化の判定にコロ トコフ音スペクトルのピーク值, 半值幅, 高周波 の変動をパラメー夕にする妥当性が示された。

\section{4. 動脈硬化危険指数}

虚血性心疾患患者のデー夕から次のような計算 式を提案する ${ }^{3)}$ 。

$$
\mathrm{Rc}=0.5 \times \mathrm{A}^{2}
$$

$\mathrm{Rc}$ : 動脈硬化危険指数

$\mathrm{A}=$ ピーク值 $/ 28.46+$ 半值幅 $/ 50.7+2$

分母の $28.46,50.7$ はそれぞれピーク值, 半値 幅の正常値上限である。また 2 は高周波の変動が ある時のみ加える。

虚血性心疾患患者での平均值 $\mathrm{Rc}=15.6$ を病的 状態とする。

この式を人間ドック受診者に適用した。動脈硬 化度を比較するものとして AI を使用した。その 結果 $\mathrm{AI}$ と動脈硬化危険指数とは良い相関が認め られだ)。ただし正常範囲にあるピーク值, 半值幅 の時はそれぞれ 1 を代入した。すなわちこの方法 ではピーク値と半值幅が正常範囲にある時は同じ 危険指数となる。しかし值が正常範囲にあっても 経時的に值が大きくなる状態は動脈硬化の進行と 考えるべきであり動脈硬化危険指数として反映さ れるべきである。したがって, 正常範囲内であっ てもピーク值, 半值幅の值をそのまま代入する。 こうして求めた動脈硬化危険指数(以下 Rc とす る）と動脈硬化危険因子との関連性を検討する。

\section{5. 動脈硬化危険因子と動脈硬化危険指数}

本研究では動脈硬化危険因子として TC, TG, AI, HDL-C, LDL-C, 喫煙, 飲酒, 家族歴を取 
り上げた。それぞれについて提案した動脈硬化危 険指数との比較を行った。なお血圧, 肥満度, 空 腹時血糖值の項目については解析した人間ドック 受診者のデータに異常が見付からなかった為検討 しなかった。

図 3 に Rc と TC の関連を示す。 Rc 值が 0 ～2 の時に TC 值が異常值を示した人数と正常值を示 した人数を棒グラフで示したものである。以下 Rc

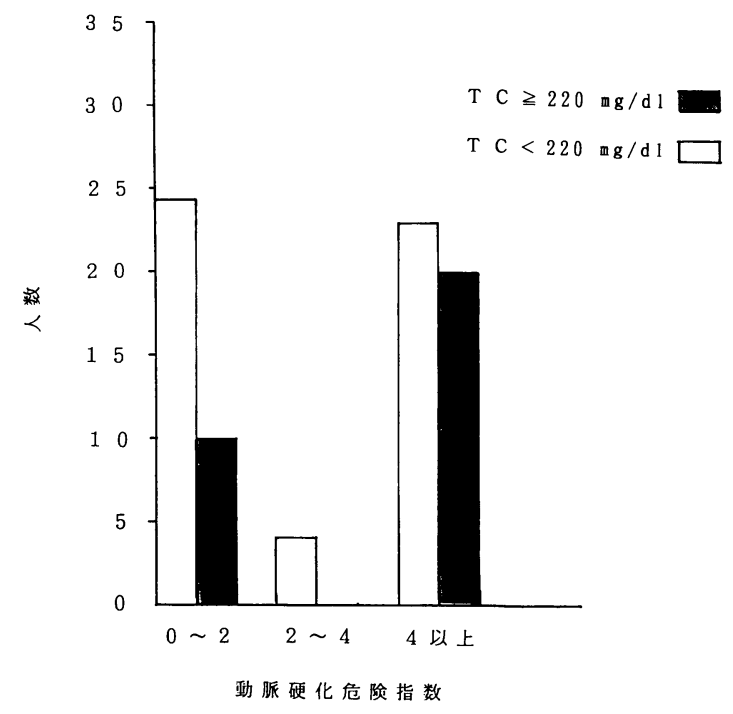

図 3 Rc 值に対する TC 值の正常, 異常群



図 5 Rc 值に対する HDL-C 值の正常, 異常群
值がが 2〜 4 の時, 4 以上の時についても同様の処 理を行った。Rc 值が 0〜2では TC 值に異常が認 められる人数は 10 人であるが Rc 值が 4 以上で は 20 人と 2 倍に増える。図 4 に $\mathrm{Rc}$ とG の関連 を, 図 5 に Rc と HDL-C の関連を, 図 6 に Rc と LDL-C の関連を, 図 7 Rc と AI との関連を示 す。Rc 值が 4 以上での TCの異常者は Rc 值が 0〜2での異常者の 2 倍であった。また Rc 值が 4

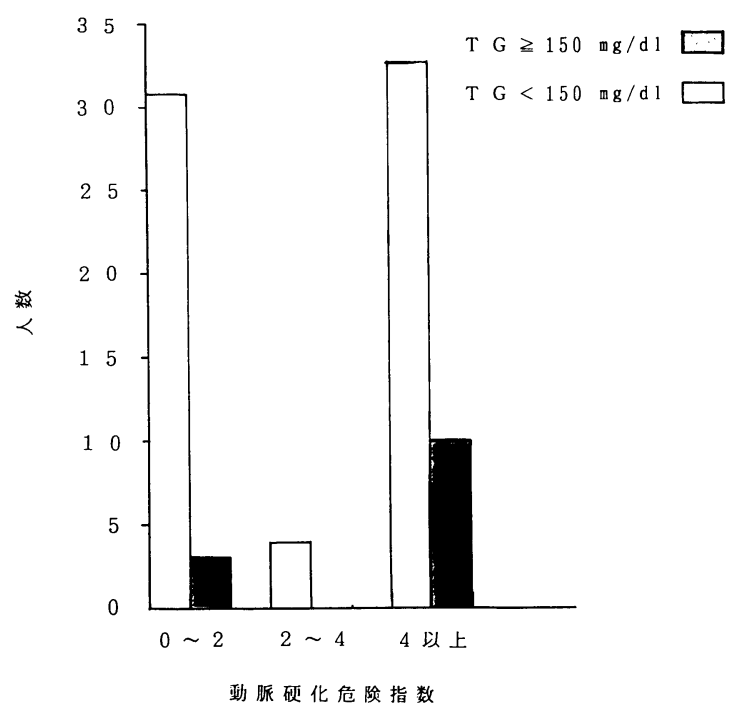

図4 Rc 值に対する TG 值の正常, 異常群

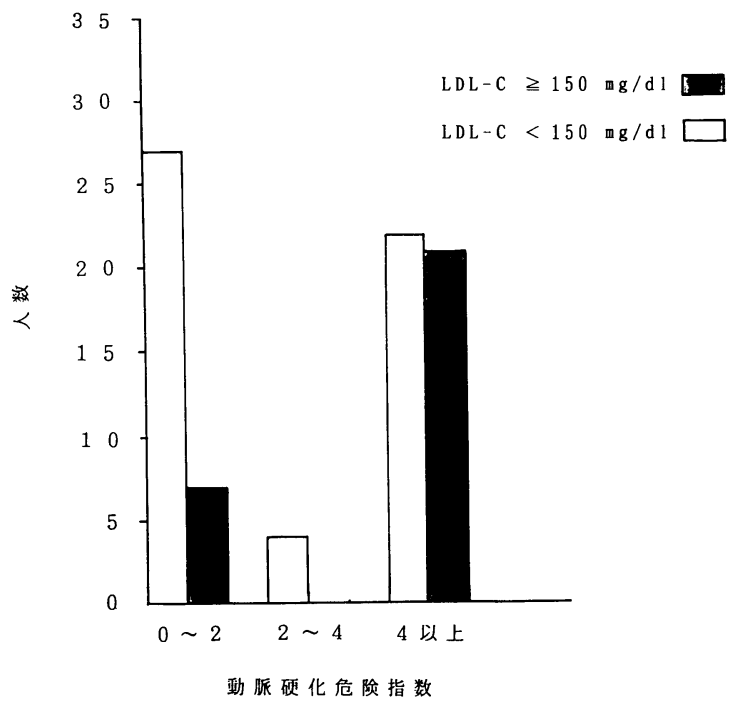

図6 Rc 值に対する LDL-C 值の正常, 異常群 


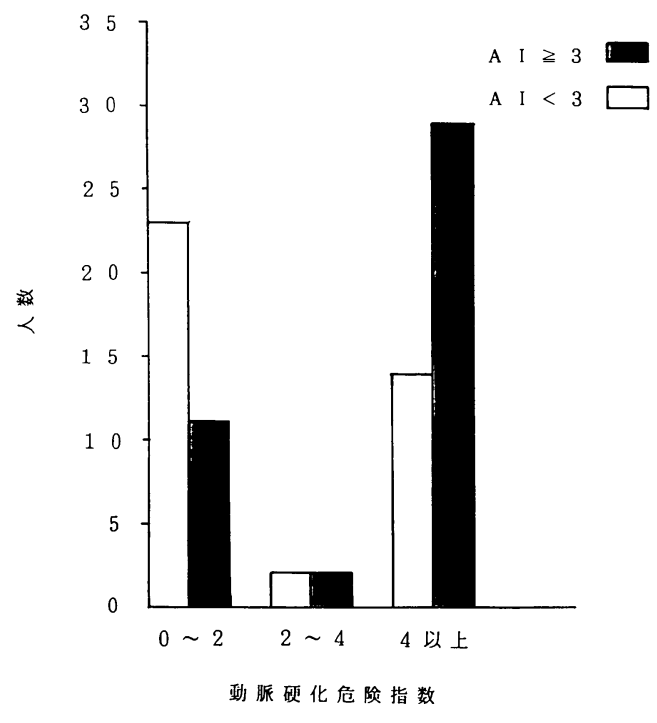

図7 Rc 值に対する AI 值の正常, 異常群

以上での LDL-C, TG, AI の異常者は Rc 值が 0 2 での異常者の 3 倍であり, HDL-C は 4 倍で あった。このことから Rc 值は AI, LDL-C, TG, HDL-Cの值に良く反映されることが分かった。

喫煙の影響を見るために現時点で 1 日 10 本以 上の喫煙者において $\mathrm{Rc}$ 值の平均值 $(\mathrm{n}=22)$ を求 め非契煙者 $(n=50)$ の平均值と比較した。喫煙者 の平均値は 5.37 となり非喫煙者の平均值 3.33 よ り 1.6 倍大きい值となり動脈硬化の危険因子であ ることが示唆された。飲酒の影響も同様に行い週 5 日以上飲酒する人 $(n=16)$ の平均值は 5.32 であ りそれ以下の飲酒の人 $(n=56)$ の平均值 3.53 よ り 1.5 倍大きい值となった。喫煙も飲酒も行って いる人 $(n=9)$ の $\mathrm{R}$ 值の平均值は 6.35 であり契 煙と飲酒の相互作用が示唆された。家族歴では父 か母が動脈硬化性疾患患者である人 $(n=14)$ の $\mathrm{Rc}$ 值の平均值は 5.63 であり家族歴のない人 $(\mathrm{n}=67)$ の $\mathrm{Rc}$ 值の平均值 3.79 より 1.48 倍大き い値となった。

\section{6. 考 察}

血圧測定時に発生するコロトコフ音は乱流に起 因すること1)，また血管が硬いほど乱流が生じゃ すい6)という知見をもとにRcという式を提案し た。Rcを求める式に含まれるコロトコフ音スペク
トルのピーク值, 半值幅, 高周波の変動は血管壁 の硬さあるいは血管壁の付着物を検出するパラメ ータであることが乱流音場理論, 音響理論から示 唆される。コロトコフ音のピーク值が高いという ことは, 血管壁が硬い為, 乱流が発生しやすいこ とを意味し高周波の変動も乱流の発生を意味して いる。さらに血管壁が硬いと発生する音も高周波 となることは明らかである。また付着物の為血管 壁が狭くなり血流速が増し乱流成分を増加させて いる。半值幅が広いことは物体の固有值が多数存 在するすなわち血管壁以外に付着物が存在してい ることを意味している。この様な意味を持つ Rc を動脈硬化危険因子と比較検討した。TC，TG， HDL-C, LDL-C, AI, 哭煙, 飲酒, 家旅歴など と Rc はそれぞれ関連性が認められた。 $\mathrm{Rc}$ 值が 4 以上の時, TC の異常值の出現率は $\mathrm{Rc}$ 值が $0 \sim 2$ の時の 2 倍であった。 Rc 值が 4 以上の時の, LDL -C, AI, TG の異常值の出現率は Rc 值が $0 \sim 2$ の 場合の 3 倍となり HDL-C は 4 倍であった。基礎 的検討のため症例数が少なく断定的な事はいえな いが動脈硬化危険因子のうち AI, TG, LDL-C, HDL-Cが重要である事が Rc 值から示唆され る。実際 LDL-C を低下させると冠動脈病変を遅 らせ ${ }^{7)} 1$ 発病と死亡率が減少する ${ }^{8,9)}$ という報告も ある。喫煙と飲酒は本症例数では同じ程度の危険 因子であり,家族歴はやや高い危険因子であった。 契煙と飲酒共に行う人の $\mathrm{Rc}$ 值の平均值は他の危 険因子の $\mathrm{Rc}$ 值の平均值よりさらに 1.2 倍程度高 くなった。これらの事より動脈硬化の危険因子と して AI, LDL-C, HDL-C, TG，家族歴，契煙と 飲酒があげられる。病的レベルの Rc 值は虚血性 心疾患患者の平均値をとり 15.6 とする。要注意レ ベルは少し厳しく 4 以上と設定した。

本研究で提案した Rc は人間ドックで適用可能 であり簡便にかつ無侵襲性定量的に直接血管壁の 硬度をしめすものであるという点ですぐれてい る。この Rc 值により各個人での動脈硬化の進度 が定量的に判定できる可能性がある。すなわち Rc 值が上昇すれば食事などに注意し要注意レベルに 到達しないように管理することもでき，治療効果 の判定などにも応用可能と思われる。また本診断 法は遺伝性高血圧のスクリーニングにも適用でき 
$3^{10)}$ 可能性を示している。現時点では基礎的検討 の為デー夕数は少なく傾向を把握する段階である が，今後はデー夕数を増やし統計的な処理を行う ことによりさらに検討を進める必要がある。例え ば多変量解析による動脈硬化性疾患の発病の予知 なども検討課題である。

\section{5. まとめ}

血圧測定時に全く無侵襲にかつ定量的に動脈硬 化の程度が診断出来るものとして，コロトコフ音 スペクトルをFFT 分析することにより血管壁の 硬度を直接反映する Rc というパラメータを提案 した。冠動脈硬化危険因子として TC, TG，HDL $-\mathrm{C}, \mathrm{LDL}-\mathrm{C}, \mathrm{AI}$ ，喫煙，飲酒，家族歴をとり， Rc 值との関連を比較検討した。その結果 TG, AI, HDL-C, LDL-C の值が異常値である群で Rc 值 4 以上の時に異常值出現率が高くまた契煙かつ飲 酒の群, 家族歴の危険因子を持つ群で $\mathrm{Rc}$ 值が高 く High risk 群として対処されるべきである事が 示唆された。また Rc 值を経時的に測定する事に より各個人についての動脈硬化の進展が把握で き，動脈硬化の予防あるいは治療効果の判定にも 応用可能と思われる。

\section{文献}

1）森反俊幸, 他：動脈硬化症の定量的診断法および血圧 測定值の誤差について, 第 1 回バイオエンジニアリン グ学術講演会, p 19 21, 東京.

2）森反俊幸，他：動脈硬化によるコロトコフ音スペクト ルの変化について, 循環制御, 12 巻 3 号, 1991 (印刷中)

3）森反俊幸, 他：動脈硬化症の無侵襲定量的診断法につ いて, 日本人間ドック学会誌, 健康医学, Vol.6, No. 1, 1991 (印刷中).

4) Friedwald WT et al: Estimation of the concentration of low-density lipoprotein cholesterol in plasma, without use of the preparative ultracentrifuge. Clin, Chem. 1972; 18: 499 502.

5）石塚毅彦,他：小心臓の先天性を示唆する臨床的所見, 第 30 回日本人間ドック学会予稿集, 255 , 東京, 1989 .

6）松信八十男，他：血管弾性と血流の基本問題，慈恵医 大シンポジウム論文集，95～106，東京， 1986 .

7) Blankenhorn DH et al: Benefical effects of combined colestipol-niacin therapy on coronary atherosclerosis and coronary venous bypass grafts. JAMA. 1987 ; $257: 3233-3240$.

8) Lipid Research Clinics Program. The Lipid Research Clinics Coronary Primary Prevention Trial results, I : reduction in the incidence of coronary heart disease. JAMA. 1984 ; $251: 351 \sim 364$.

9) Frick $\mathrm{MH}$ et al : Helsinki Heart Study : primaryprevention trial with gemfibrozil in middle-aged men with dyslipidemia. N Engl J Med. 1987 ; 317 : 1237〜1245.

10）森反俊幸, 他：遺伝性高血圧のスクリーニングについ て, 第 31 回日本人間ドック学会, p 203, 浜松, 1990 . 